\title{
OPEN Antimonate sequestration from aqueous solution using zirconium, iron and zirconium-iron modified biochars
}

\author{
Md. Aminur Rahman 1,3, Mohammad Mahmudur Rahman ${ }^{1}$, Md. Mezbaul Bahar $^{1}$, \\ Peter Sanderson ${ }^{1} \&$ Dane Lamb ${ }^{2 \bowtie}$
}

Antimony (Sb) is increasingly being recognized as an important contaminant due to its various industrial applications and mining operations. Environmental remediation approaches for $\mathrm{Sb}$ are still lacking, as is the understanding of Sb environmental chemistry. In this study, biosolid biochar (BSBC) was produced and utilized to remove antimonate $(\mathrm{Sb}(\mathrm{V}))$ from aqueous solution. Zirconium ( $\mathrm{Zr})$, Zirconium-iron ( $\mathrm{Zr}-\mathrm{Fe}$ ) and $\mathrm{Fe}-\mathrm{O}$ coated $\mathrm{BSBC}$ were synthesized for enhancing $\mathrm{Sb}(\mathrm{V})$ sorption capacities of BSBC. The combined results of specific surface area, FTIR, SEM-EDS, TEM-EDS, and $X P S$ confirmed that $Z r$ and/or Zr-Fe were successfully coated onto BSBC. The effects of reaction time, $\mathrm{pH}$, initial $\mathrm{Sb}(\mathrm{V})$ concentration, adsorbate doses, ionic strength, temperature, and the influence of major competitive co-existing anions and cations on the adsorption of $\mathrm{Sb}(\mathrm{V})$ were investigated. The maximum sorption capacity of $\mathrm{Zr}-\mathrm{O}, \mathrm{Zr}-\mathrm{Fe}, \mathrm{Zr}-\mathrm{FeCl}{ }_{3}, \mathrm{Fe}-\mathrm{O}$, and $\mathrm{FeCl}_{3}$ coated $\mathrm{BSBC}$ were 66.67, 98.04, $85.47,39.68$, and $31.54 \mathrm{mg} / \mathrm{g}$ respectively under acidic conditions. The XPS results revealed redox transformation of $\mathrm{Sb}(\mathrm{V})$ species to $\mathrm{Sb}$ (III) occurred under oxic conditions, demonstrating the biochar's ability to behave as an electron shuttle during sorption. The sorption study suggests that $\mathrm{Zr}-\mathrm{O}$ and $\mathrm{Zr}-\mathrm{O}-\mathrm{Fe}$ coated BSBC could perform as favourable adsorbents for mitigating $\mathrm{Sb}(\mathrm{V})$ contaminated waters.

Anthropogenic activities such as mining, smelting and metallurgy, combustion of fossil fuels, production of flame-retardants, catalysis of plastic production, semiconductors, amongst others, are increasingly important sources of antimony $(\mathrm{Sb})$ in the environment ${ }^{1,2}$. Antimony contamination has received growing attention primarily due to its increasing industrial applications and the relatively limited knowledge on environmental toxicity, transformations and fate in the environment ${ }^{3,4}$. In natural waters, $\mathrm{Sb}$ exists in both trivalent ( $\mathrm{Sb}(\mathrm{III})$ and pentavalent $\left(\mathrm{Sb}(\mathrm{V})\right.$ oxidation states. Trivalent $\mathrm{Sb}$ mainly exists as $\mathrm{Sb}(\mathrm{OH})_{3}{ }^{0}$ and $\mathrm{SbO}(\mathrm{OH})^{0}$ at $\mathrm{pH} 2-10$, in the form of $\mathrm{SbO}^{+}$and $\mathrm{Sb}(\mathrm{OH})_{2}{ }^{+}$at $\mathrm{pH}<2$, but can also can be present as $\mathrm{SbO}_{2}^{-}$and $\mathrm{Sb}(\mathrm{OH})_{4}{ }^{+}$at $\mathrm{pH}>10.4$. Pentavalent $\mathrm{Sb}$ exists mainly as $\mathrm{Sb}(\mathrm{OH})_{6}{ }^{-}$at $\mathrm{pH}>2.7^{5,6}$. The toxicity and mobility depends on the $\mathrm{Sb}$ oxidation state, with $\mathrm{Sb}$ (III) exhibiting tenfold greater toxicity than $\mathrm{Sb}(\mathrm{V})^{7-9}$. In addition, antimony trioxide $\left(\mathrm{Sb}_{2} \mathrm{O}_{3}\right)$ has been identified as a carcinogenic to humans (Group 2B) by IARC ${ }^{10}$.

Considering the increasing threat posed by $\mathrm{Sb}$ in the environment, several technologies have been trialled to remove excess $\mathrm{Sb}$ from natural waters. Remediation technologies to date rely on (ad)sorption, coagulation, electrocoagulation, co-precipitation, electrodeposition and membrane techniques ${ }^{11}$. Due to the expensive operational and maintenance costs involved in such processes, most of these techniques have limitations in removing $\mathrm{Sb}$. The adsorption process has emerged as a promising and viable approach due to its economical nature, high efficiency, simplicity, technical flexibility, and social acceptability ${ }^{12,13}$.

Several adsorbents have been investigated for Sb removal from natural and industrial waters, including multiwalled carbon nanotubes ${ }^{14}$, hydrated ferric oxide supported by calcite sand ${ }^{15}$, graphene ${ }^{16}$, Fe-modified aerobic granules $^{17}$, and $\mathrm{Fe}-\mathrm{Mn}$ binary oxide ${ }^{18}$. The adsorption capacity of these materials tends to be poor. Only a few sorbents such as metal-loaded $\mathrm{Zr}$ (IV), Fe(III) saponified orange waste ${ }^{19}$, zero-valent iron nanoparticles coatings on aluminum and silicon minerals ${ }^{20,21}$, iron oxyhydroxides, zirconium oxide ( $\left.\mathrm{Zr}-\mathrm{O}\right)$-carbon nanofibers ${ }^{13}$,

${ }^{1}$ Global Centre for Environmental Remediation (GCER), The University of Newcastle, Callaghan, Australia. ${ }^{2}$ Global Innovation Centre for Advanced Nanomaterials, The University of Newcastle, Advanced Technology Centre - Room 181, University Drive, Callaghan, NSW 2308, Australia. ${ }^{3}$ Department of Public Health Engineering (DPHE), Zonal Laboratory, Khulna 9100, Bangladesh. ${ }^{\boxplus e m a i l: ~ d a n e . l a m b @ n e w c a s t l e . e d u . a u ~}$ 
reduced graphene oxide $/ \mathrm{Mn}_{3} \mathrm{O}_{4}{ }^{22}, \mathrm{MnO}_{2}$ nanofibers ${ }^{23,24}, \mathrm{TiO}_{2}{ }^{24}$, and $\mathrm{UiO}-66 \mathrm{NH}_{2}{ }^{25}$ have reported promising results for both $\mathrm{Sb}(\mathrm{III})$ and $\mathrm{Sb}(\mathrm{V})$ adsorption. However, readily available and cost-effective materials are required to remediate $\mathrm{Sb}$ from contaminated water.

Recently, biochar has received notable attention as environmentally friendly and effective adsorbents, costefficient materials for the remediation treatment of metal(loid) $s^{26}$. Although several studies have documented $\mathrm{Sb}$ adsorption to pure minerals ${ }^{27,28}$ and humic substances ${ }^{29,30}$, very few studies of $\mathrm{Sb}$ sorption onto biochars have been reported to date ${ }^{31,32}$. Antimonate can strongly bind to $\mathrm{Fe}(\mathrm{OH})_{2} / \mathrm{Fe}(\mathrm{OH})_{3}$, but, the bonding environment is still not clearly resolved ${ }^{33,34}$. Similarly, little is currently known on the Sb sorption by biochars, sorption mechanisms and the possible surface transformations which may occur.

Biochars have been modified to improve the sorption properties for oxyanions such as Sb and As. For instance, one study investigated the elimination of $\mathrm{Sb}$ (III) using different metal oxide composites consisting of Fe and $\mathrm{Mn}^{18}$. Hydrous $\mathrm{Zr}-\mathrm{O}$ is known to display ion exchange ability, and specific binding potentiality of $\mathrm{Zr}$ (IV) to different oxyanions due to its strong $\mathrm{Zr}$ (IV)-O bonds ${ }^{35}$. The excellent performance of Zr-based metal organic frameworks were presented in removing $\mathrm{Sb}$ and As from water ${ }^{25}$. Ren et al. ${ }^{36}$ demonstrated the high removal capacity for As using $\mathrm{Fe}-\mathrm{Zr}$ binary oxide. Being from the same group (group V), As and Sb share some similar properties, but also show contrasting interactions with $\mathrm{Fe}$ and organic moeities ${ }^{30,37}$.

In this study, we report the $\mathrm{Sb}(\mathrm{V})$ removal with modified and unmodified biochars and potential redox transformations associated with biochar. The objectives of this study were to: (1) synthesise a series of $\mathrm{Zr}$ treated biochar, $\mathrm{Zr}-\mathrm{Fe}$ treated biochar and Fe treated biochar by a co-precipitation method, and (2) evaluate the adsorption performance of $\mathrm{Sb}(\mathrm{V})$ in aqueous solution as controlled by solution $\mathrm{pH}$, adsorbate dosage, reaction time, initial concentration, temperature, influence of major coexisting cations and anions, surface charge, and surface area. In addition, we explored the surface transformation of $\mathrm{Sb}(\mathrm{V})$ to $\mathrm{Sb}(\mathrm{III})$ under oxic conditions with X-ray photoelectron spectroscopy (XPS).

\section{Results and discussion}

Biochar characterization. The zeta potential of all biochars in the range of $\mathrm{pH} 2-11$ varied between +25.02 to $-35.54 \mathrm{mV}$ (Table S1 in Supporting Information (SI) section). Increasing $\mathrm{pH}$ translated to increasing negative surface charge of pristine biochars. The net surface charge of modified $\mathrm{Zr}-\mathrm{FeCl}_{3} \mathrm{BSBC}(1: 5)$ and $\mathrm{Zr}-\mathrm{FeBSBC}(1: 20)$ carried positive charge up to $\mathrm{pH} 5$ and 6 , whereas $\mathrm{Zr}-\mathrm{BSBC}_{6.5}, \mathrm{Zr}-\mathrm{BSBC}_{12.5}, \mathrm{Fe}-\mathrm{BSBC}$, and $\mathrm{FeCl}_{3}-\mathrm{BSBC}_{\text {carried }}$ a positive surface charge at $\mathrm{pH}<3$. At low $\mathrm{pH}$, the net protonation from the medium was enough to balance the negative charge of all biochars. The iso-electric point was reached at $\mathrm{pH} 2-6$ (Table S1). The physico-chemical characteristics and elemental composition of biochars are provided in Table S2 and Table S3, respectively.

The surface functional groups of modified biochars analyzed by FTIR are presented in Fig. 1. The most prominent, broad and strong bands occurred at around $3400 \mathrm{~cm}^{-1}$, corresponding to the stretching and bending vibrations of $-\mathrm{OH}$ functional groups of tightly bonded water molecules (Fig. 1A) ${ }^{31,32,38}$. The peak at $1640 \mathrm{~cm}^{-1}$ was explained by the deformation of water molecules and indicated physio-sorbed $\mathrm{H}_{2} \mathrm{O}$ on the adsorbent by oxide ${ }^{32,36}$. Previous studies also support this ${ }^{39,40}$. The spectra at around $2900 \mathrm{~cm}^{-1}$ could be attributed to $\mathrm{CH}_{3}-$ stretching which exists in all biochars; similar findings were reported by Vithanage et al. ${ }^{32}$.

A spectral shift of 2915-2960 and 2845-2865 $\mathrm{cm}^{-1}$ occurred due to $\mathrm{Zr}$ and/or Fe modifications compared to the pristine biochar (Fig. 1A). The two spectrum bands at 3694 and $3791 \mathrm{~cm}^{-1}$ (Fig. 1A) ascribed to freely vibrating surface hydroxyl groups can be found in $\mathrm{BSBC}, \mathrm{FeBSBC}$ and $\mathrm{FeCl}_{3} \mathrm{BSBC}$. However, after $\mathrm{Zr}$-modification the bands shifted to 3646,3671 , and $3687 \mathrm{~cm}^{-1}$, which is responsible for $\mathrm{ZrO}_{2}$ monoclinic $(\mathrm{Zr}-\mathrm{OH})$ and tetragonal $\left(\mathrm{Zr}-\mathrm{OH}-\mathrm{Zr} \text { ) (Fig. 1A) crystalline super structure (tri-bridges } \mathrm{OH}-\text { groups on } \mathrm{Zr}^{4+}\right)^{41}$. Moreover, the band at $3746 \mathrm{~cm}^{-1}$ could arise from the $\mathrm{SiO}_{2}$ group. The bands $1522,1541,1544,1559$, and $1574 \mathrm{~cm}^{-1}$ were due to $\mathrm{Zr}-\mathrm{OH}$ vibrations ${ }^{42}$ found in the $\mathrm{Zr}$ and/or Fe-modified BSBC. The $\mathrm{Zr}$ and $\mathrm{P}$ peaks always overlapped. In addition, peaks at $1315,1339,1343,1397,1418$, and $1420 \mathrm{~cm}^{-1}\left(1300-1420 \mathrm{~cm}^{-1}\right)$ ascribed to carboxylate groups ${ }^{36}$ were developed in Zr-modified biochars (Fig. 1B). This was due to the deformation vibration of $\mathrm{Zr}-\mathrm{OH}$. Samples reacted with $\mathrm{Sb}(\mathrm{V})$ demonstrated a new sharp band at $1384 \mathrm{~cm}^{-1}$ (Fig. 1C,D) which was not observed in unreacted biochars. The absorption band is attributed to the $\mathrm{Sb}-\mathrm{O}$ bond. Another distinguishable feature is that the structure of the spectra at $795 \mathrm{~cm}^{-1}$ of $\mathrm{Sb}(\mathrm{V})$ reacted biochar was sharper than the $\mathrm{Sb}(\mathrm{V})$-unreacted biochar (Fig. 1D).

Figure S1 shows representative SEM images of each of the biochars. Distinct micropores were observable, especially in the unmodified BSBC biochars. Figure S1(i-ii); and B(i-ii) to G(i-ii), represents the morphology and surface characteristics of pristine BSBC and different modified biochars, respectively, before the sorption of $\mathrm{Sb}(\mathrm{V})$ at two different magnifications. Similarly, Figure S1(iii), and 2B(iii)-G(iii) describes the morphology and surface texture of Sb-loaded pristine, and Sb-loaded modified biochar-composites, respectively, after sorption of $\mathrm{Sb}(\mathrm{V})$ from aqueous solution. The morphology and surface texture of modified biochars contrasted from one another, which were covered by high densities of fine $\mathrm{Zr}$, or $\mathrm{Zr}-\mathrm{Fe}$ particles. Moreover, some fractions of $\mathrm{Zr}$ (IV) were located randomly onto the biochar surface which indicates a heterogeneous coating of these metals occurred during co-precipitation [Figure S1 B(i)-E(i)].

The SEM-EDS spectrum of $\mathrm{ZrBSBC}_{6.5}, \mathrm{ZrBSBC}_{12.5}, \mathrm{Zr}-\mathrm{FeBSBC}(1: 20)$ and $\mathrm{Zr}-\mathrm{FeCl}_{3} \mathrm{BSBC}(1: 5)$ confirmed the presence of $\mathrm{Zr}$ in the $\mathrm{Zr}$ and/or $\mathrm{Zr}$-Fe-modified biochars at $2.042 \mathrm{keV}$ [Figure S2 B(i)-E(i)]; and Figure S2 $\mathrm{A}(\mathrm{i}), \mathrm{S} 2 \mathrm{~F}(\mathrm{i})$ and S2 G(i) represents the SEM-EDS of pristine BSBC, FeBSBC and $\mathrm{FeCl}_{3} \mathrm{BSBC}$, respectively. After sorption of $\mathrm{Sb}(\mathrm{V})$ onto these adsorbents and the characteristic peaks at $3.604 \mathrm{keV}$ in the EDX spectra [Figure S2 $\mathrm{A}(\mathrm{ii})-\mathrm{G}(\mathrm{ii})]$, this confirmed the existence of sorbed $\mathrm{Sb}(\mathrm{V})$ along with $\mathrm{C}, \mathrm{O}, \mathrm{N}, \mathrm{Fe}, \mathrm{P}, \mathrm{Sb}$, and $\mathrm{Zr}$. However, SEM-EDS spectra of P (K-line $2.013 \mathrm{keV}$ ) and Zr (L-line $2.042 \mathrm{keV}$ ) in biochars may not be clearly differentiated due to their very close X-ray energy levels. Thus, overlapping spectra of $\mathrm{P}$ and $\mathrm{Zr}$ was observed. To overcome this issue, TEM-EDS was performed where the $\mathrm{Zr} \mathrm{K}$-line was confirmed at $15.744 \mathrm{keV}$ and could be differentiated from the P K-line. The SEM-EDS analysis also provided evidence that Zr-FeBSBC (1:20) showed substantial 


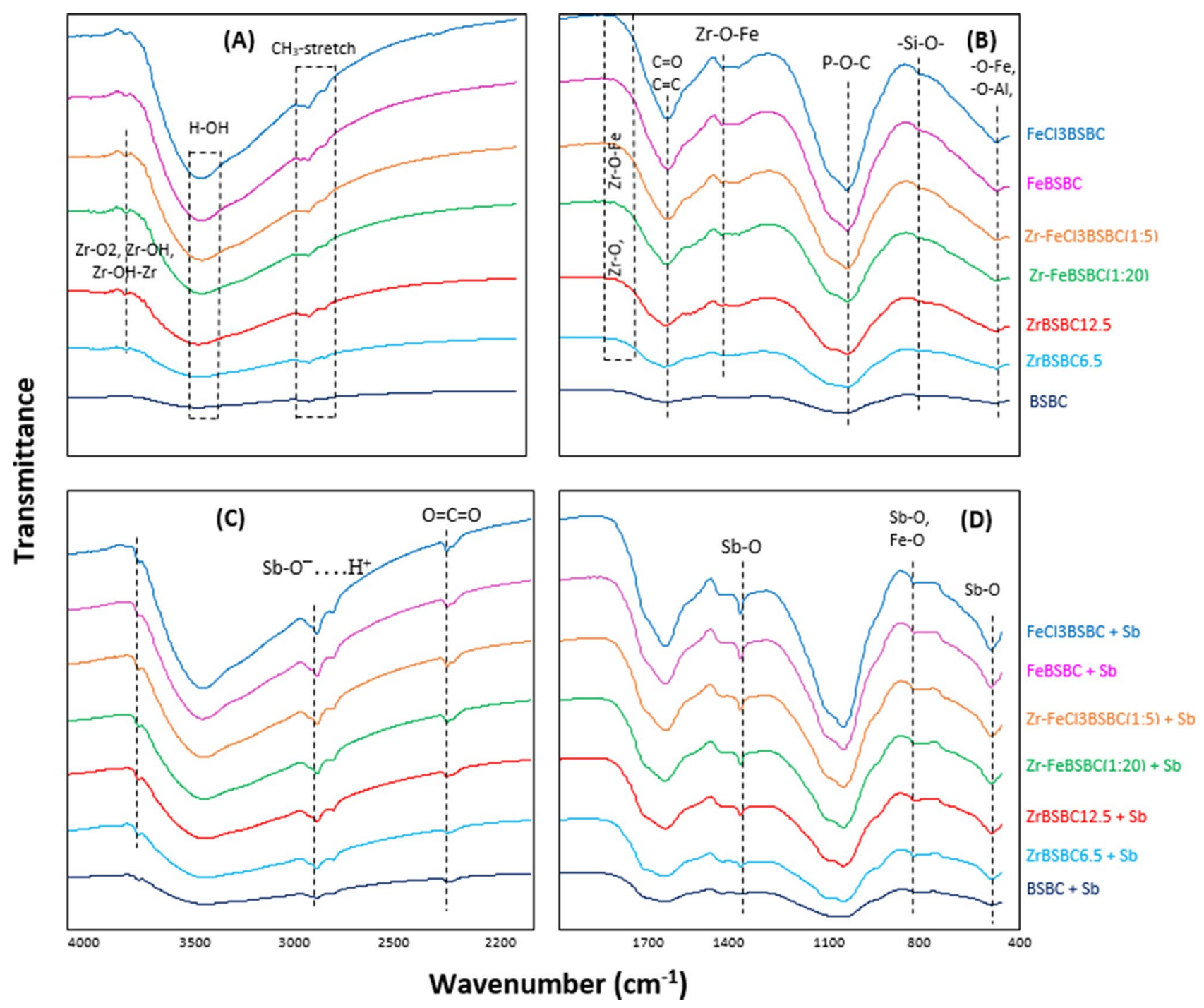

Figure 1. FTIR Spectra of biochars before $(\mathbf{A}, \mathbf{B})$ and after $(\mathbf{C}, \mathbf{D}) \mathrm{Sb}(\mathrm{V})$-sorption.

wt. (\%) distribution of $\mathrm{Sb}(\mathrm{V})$ (10.94 wt. \%) than other biochars, indicating Zr-FeBSBC (1:20) possessed a high $\mathrm{Sb}(\mathrm{V})$ sorption efficiency.

The TEM images of pristine BSBC, $\mathrm{ZrBSBC}_{12.5}$ and $\mathrm{Zr}-\mathrm{FeBSBC}(1: 20)$ are shown in Figure S3. Results from EDS-TEM elemental mapping indicated that $\mathrm{C}, \mathrm{O}, \mathrm{Ca}, \mathrm{P}, \mathrm{Si}, \mathrm{S}, \mathrm{Ca}, \mathrm{K}, \mathrm{Mg}$, were the major elements in biochar structure, yet the intensity and brightness of $\mathrm{C}, \mathrm{O}, \mathrm{P}$ and $\mathrm{Ca}$ were more noticeable in pristine BSBC (Figure S3A). TEM elemental images also confirmed the presence of $\mathrm{Zr}$ and $\mathrm{Zr}-\mathrm{Fe}$ in $\mathrm{Zr}-\mathrm{BBSC}_{12.5}$ and $\mathrm{Zr}-\mathrm{FeBSBC}(1: 20)$ (Figure S3C and S3D). The TEM-EDS spectrum of $\mathrm{ZrBSBC}_{12.5}$ and $\mathrm{Zr}-\mathrm{FeBSBC}(1: 20)$ confirmed the presence of $\mathrm{Zr}$ (K-line) (mass percentage $15.06 \%$ and $2.79 \%$, respectively) located heterogeneously on the biochar surfaces, suggesting the procedure successfully coated $\mathrm{Zr}$ with biochar at $2.042 \mathrm{keV}$ (L-line) (Figure S4 in SI section). Characteristic $\mathrm{Sb}$ spectra were identified characteristics Sb spectra were found after sorption of $\mathrm{Sb}(\mathrm{V})$ with BSBC (Sb mass 15.44\%), $\mathrm{ZrBSBC}_{12.5}$ (Sb mass 3.45\%, Zr mass 11.80\%) and Zr-FeBSBC(1:20) (Sb mass $5.34 \%$, Zr mass $0.73 \%$ ) (see Figure S4 in SI Section). However, TEM images demonstrate different forms of non-uniform nanosized $\mathrm{Zr}$ and $\mathrm{Sb}$ crystals (Fig. 2). The lattice planes could be clearly sighted with a $d$-spacing at $0.35 \mathrm{~nm}$, characteristic of the (111) plane of the Zr-crystalline tetragonal phase ${ }^{43}$ (Fig. 2). The formation of $\mathrm{Sb}$ crystal features on the biochar surfaces indicates surface modification and transformation of $\mathrm{Sb}$ to a possible 3-dimensional feature on the surface.

The results from XPS analysis similarly confirmed the transformation of $\mathrm{Sb}(\mathrm{V})$ at the surface of all biochars (Fig. 3). The two peaks of $\mathrm{Sb} 3 \mathrm{~d} 3$ and $\mathrm{Sb} 3 \mathrm{~d} 5$ are located at binding energies of 531.6 and $540.7 \mathrm{eV}$ after sorption of $\mathrm{Sb}$ (Fig. 3A) which demonstrates the existence of both $\mathrm{Sb}(\mathrm{V})$ and $\mathrm{Sb}$ (III) species on the biochar surface. The appearance of two $\mathrm{Sb}$ peaks suggests that the reduction of $\mathrm{Sb}(\mathrm{V})$ to $\mathrm{Sb}(\mathrm{III})$ occurred during sorption by pristine BSBC as well as $\mathrm{Zr}$-modified, $\mathrm{Zr}$-Fe modified and Fe-modified biochars under oxidizing environments. Previous research on As has indicated redox transformations may occur during reaction with pyrolised organic materials, such as the surface of biochars ${ }^{31}$. Kappler et al. ${ }^{44}$ demonstrated that biochar particles under reducing conditions acted as an electron shuttle, resulting in redox transformation of $\mathrm{Fe}$ and potentially other redox sensitive elements. 


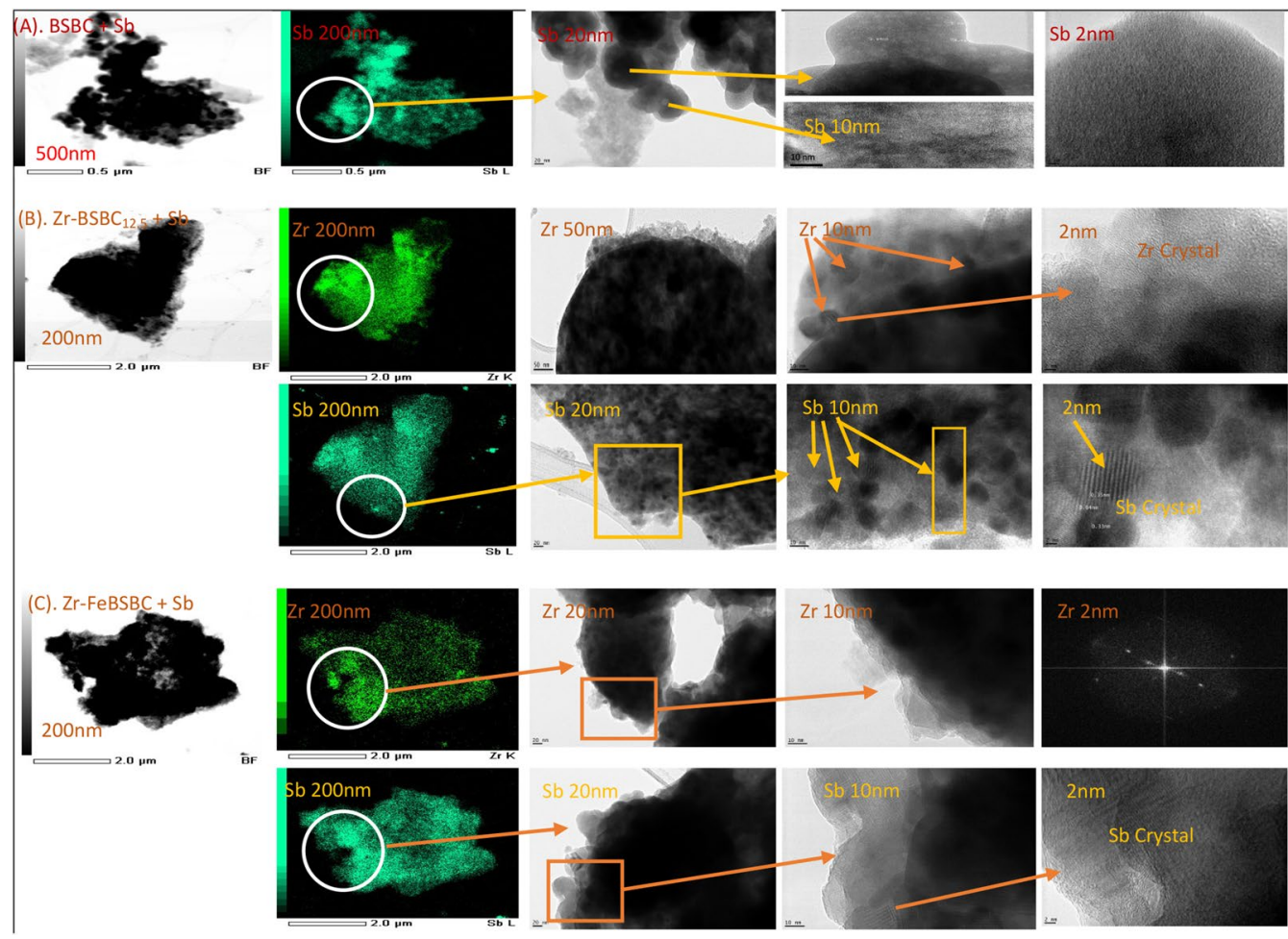

Figure 2. Different magnifications of $\mathrm{Sb}(\mathrm{V})$ and $\mathrm{Zr}$ onto Sb-loaded (A) BSBC, (B) $\mathrm{ZrBSBC}_{12.5}$, and (C) $\mathrm{Zr}-\mathrm{FeCl}_{3} \mathrm{BSBC}$ biochars revealed by TEM imaging ( $\mathrm{Zr}$ and $\mathrm{Sb}$-crystallinity).

The current work indicates, that even under oxidizing conditions, biochar surfaces may promote reductive transformation of Sb during reaction, whether modified with $\mathrm{Zr}$ (Fig. 3B) or Fe (Fig. 3D).

The $\mathrm{O}_{\mathrm{ad}} / \mathrm{O}_{\text {latt }}$ ratio increased from 1.0 to 1.21 and 1.0 to 1.11 from BSBC to $\mathrm{ZrBSBC}_{12.5}$ and FeBSC after Sb sorption, respectively. However, this ratio decreased to 0.55 in $\mathrm{Zr}-\mathrm{FeBSBC}(1: 20)$ due to the incorporation of additional $\mathrm{Fe}$ association with $\mathrm{Zr}$. In addition, the Fe content decreased from 0.51 to 0.17 at \% for $\mathrm{ZrBSBC}_{12.5}$ compared to pristine BSBC. Interestingly, the Fe content increased for $\mathrm{Zr}-\mathrm{Fe}$ (0.51-0.56 at.\%) and Fe-modified (0.51-0.66 at.\%) biochars compared to pristine biochar. Therefore, the $\mathrm{Zr}-\mathrm{O}, \mathrm{Zr}-\mathrm{O}-\mathrm{Fe}$ or $\mathrm{Fe}-\mathrm{O}$ site play significant role for enhanced Sb sorption by $\mathrm{Zr}-\mathrm{BSBC}, \mathrm{Zr}-\mathrm{FeBSBC}$ and FeBSBC.

The chemical composition of pristine BSBC, $\mathrm{ZrBSBC}_{12.5}, \mathrm{Zr}-\mathrm{FeBSBC}(1: 20)$ and FeBSBC after Sb(V) sorption was characterized by XPS. The XPS survey spectrum clearly showed the corresponding peaks to $\mathrm{O} 1 \mathrm{~s}(531.65 \mathrm{eV})$, $\mathrm{N} 1 \mathrm{~s}(400.21 \mathrm{eV}), \mathrm{C} 1 \mathrm{~s}(284.8 \mathrm{eV}), \mathrm{P} 2 \mathrm{p}(133.77 \mathrm{eV}), \mathrm{Fe} 2 \mathrm{p}$ (711.83), and Sb 3d (540.65 eV) (Figure S5). The XPS survey spectra confirmed the successful bonding of $\mathrm{Zr}$ onto $\mathrm{ZrBSBC}_{12.5}(\mathrm{Zr} 3 \mathrm{~d} 5$ at 182.76 and $\mathrm{Zr} 3 \mathrm{~d} 3$ at $185.45 \mathrm{eV})$ and $\mathrm{Zr}-\mathrm{FeBSC}(1: 20)$ ( $\mathrm{Zr} 3 \mathrm{~d} 5$ at 183.17 and $\mathrm{Zr} 3 \mathrm{~d} 3$ at $185.36 \mathrm{eV})$ surface (Fig. 3B,C). The two Zr 3d peaks can be observed at two binding energies and exists in $(+) 4$ oxidation state ${ }^{45}$. The peak at approximately 182.76 and $185.36 \mathrm{eV}$ represent to the a $\mathrm{Zr}-\mathrm{O}$ bonds while the peaks at approximately 182.81 and $185.36 \mathrm{eV}$ correspond to the metallic Zr bonds (Zr-Zr) which was slightly shifted by loading of Sb (Fig. 3B,C) ${ }^{13}$.

Antimonate sorption to biochars. Effect of $p H$. The highest adsorption (85-96\%) appeared at a broader range of $\mathrm{pH}$ 2-6 for modified $\mathrm{Zr}-\mathrm{FeBSBC}(1: 20)$ and $\mathrm{Zr}-\mathrm{FeCl}_{3} \mathrm{BSBC}$ (1:5), whereas for pristine $\mathrm{BSBC}$ the rates were low between $\mathrm{pH} 3$ and 8 , which sharply declined at $\mathrm{pH} 8$ (25\%) (Fig. 4A).

At $\mathrm{pH}<5$, the biochar composites behave as weak acids and formed positivity charged surfaces sites. Since most of the metallic oxides/hydroxides demonstrated amphoteric surface characteristics, the $\mathrm{Zr} / \mathrm{Fe}$ oxides could be protonated at acidic $\mathrm{pH}$ by the following reactions:

$$
\begin{array}{lll}
\equiv \mathrm{Zr}-\mathrm{OH} & +\mathrm{H}^{+} \rightleftharpoons \mathrm{H}^{+} \rightleftharpoons \mathrm{Zr}-\mathrm{OH}_{2}{ }^{+} \\
\equiv \mathrm{Fe}-\mathrm{OH} \quad & + & \rightleftharpoons \mathrm{Fe}-\mathrm{OH}_{2}{ }^{+}
\end{array}
$$

\begin{tabular}{|c|c|c|c|c|c|c|}
\hline$\equiv \mathrm{Zr}-\mathrm{OH}$ & + & $\mathrm{OH}^{-}$ & $\leftrightharpoons$ & $\equiv \mathrm{Zr}-\mathrm{O}^{-}$ & + & $\mathrm{H}_{2} \mathrm{O}$ \\
\hline$\equiv \mathrm{Fe}-\mathrm{OH}$ & + & $\mathrm{OH}^{-}$ & $\leq$ & $\equiv \mathrm{Fe}^{-\mathrm{O}^{-}}$ & + & $\mathrm{H}_{2} \mathrm{O}$ \\
\hline
\end{tabular}

The $\mathrm{Zr} / \mathrm{Fe}$ oxides could be deprotonated at basic $\mathrm{pH}$ by the following reactions: 


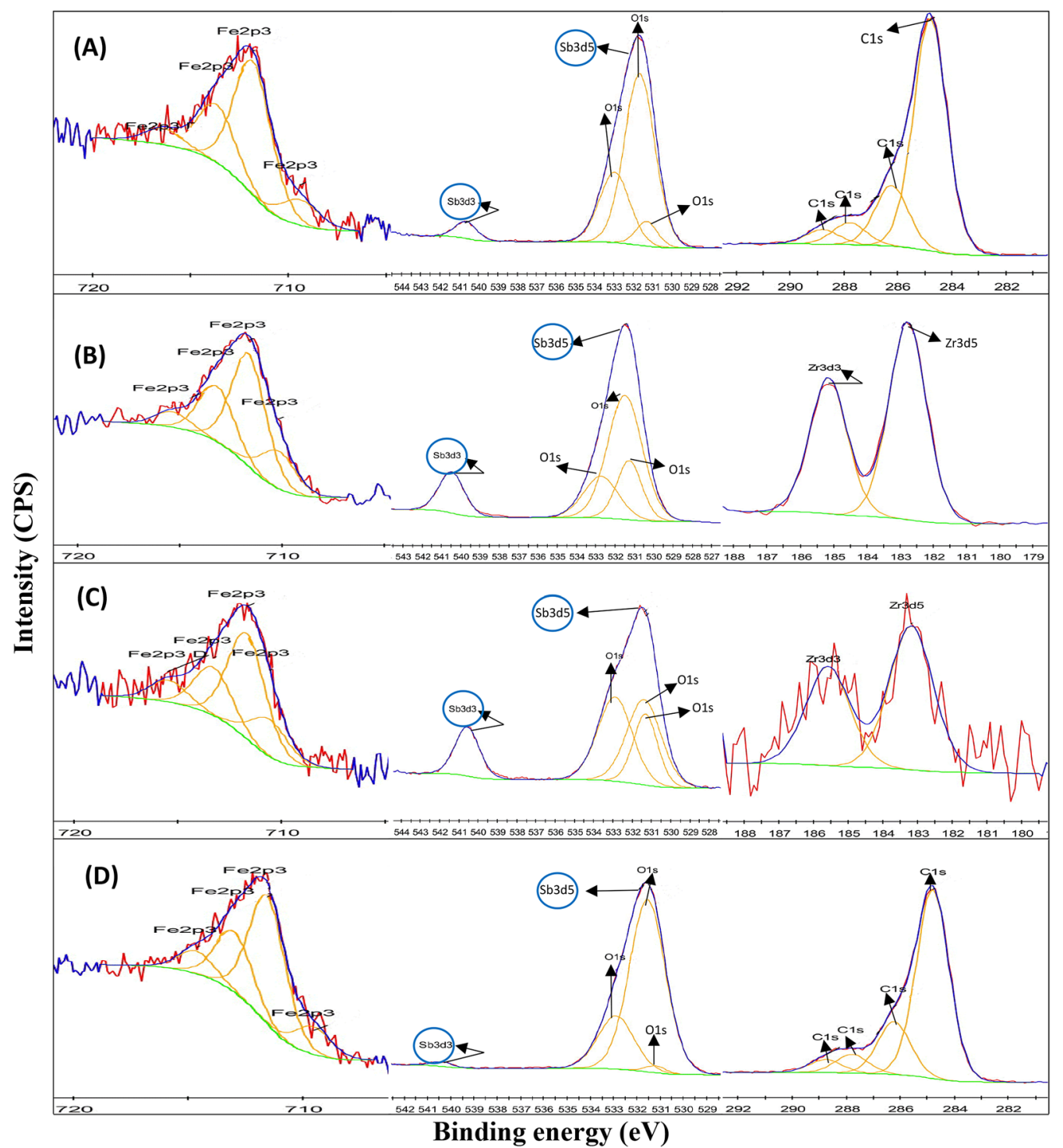

Figure 3. XPS expanded peaks of Sb-loaded BSBC (A), ZrBSBC12.5 (B), Zr-FeBSBC(1:20) (C) and FeBSBC (D).

(A)

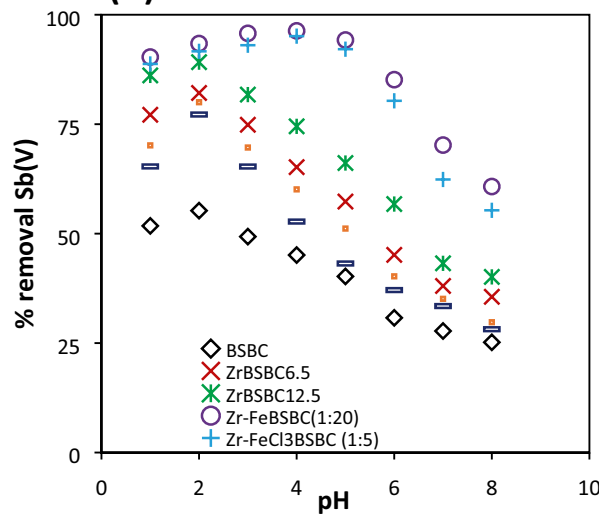

(B)

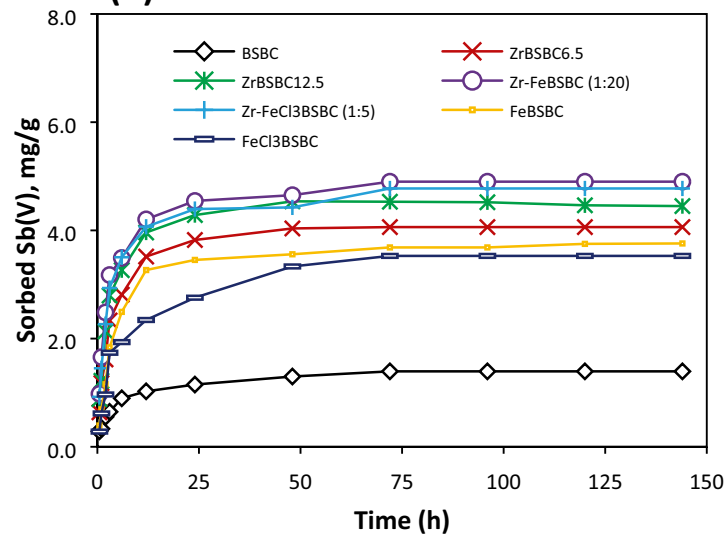

Figure 4. Effect of $\mathrm{pH}$ on removal percentage (\%) of $\mathrm{Sb}(\mathrm{V}),(\mathbf{A})$ [Initial concentration was $20 \mathrm{mg} / \mathrm{L} \mathrm{Sb}(\mathrm{V})$, biochar dosage was $4 \mathrm{~g} / \mathrm{L}$, temperature was $22^{\circ} \mathrm{C}$ ] and effect of time on sorption capacity of $\mathrm{Sb}(\mathrm{V}),(\mathrm{B})$ [Initial concentration $5 \mathrm{mg} / \mathrm{L}$ for BSBC, and $20 \mathrm{mg} / \mathrm{L}$ for $\mathrm{ZrBSBC}_{6.5}, \mathrm{ZrBSBC}_{12.5}, \mathrm{Zr}-\mathrm{FeBSBC}(1: 20), \mathrm{Zr}-\mathrm{FeCl}_{3} \mathrm{BSBC}$ (1:5), $\mathrm{Fe}-\mathrm{BSBC}$ and $\mathrm{FeCl}_{3}-\mathrm{BSBC} \mathrm{Sb}(\mathrm{V})$, biochar dosage was $4 \mathrm{~g} / \mathrm{L}$, temperature was $\left.22^{\circ} \mathrm{C}\right]$. 


\begin{tabular}{|c|c|c|c|c|c|c|c|c|c|c|c|c|c|c|c|}
\hline \multirow[b]{2}{*}{ Biochar } & \multirow[t]{2}{*}{$q_{\text {e-exp }}(m g / g)$} & \multicolumn{3}{|c|}{ Pseudo first-order } & \multicolumn{4}{|c|}{ Pseudo second-order } & \multicolumn{3}{|l|}{ Elovich } & \multicolumn{3}{|c|}{ Intraparticle diffusion } & \multirow[b]{2}{*}{$\mathrm{pH}$} \\
\hline & & $k_{1}\left(h^{-1}\right)$ & qe-cal & $\mathbf{R}^{2}$ & $\begin{array}{l}\mathbf{k}_{2}(\mathrm{~g} \\
\left.\mathrm{mg}^{-1} \mathbf{h}^{-1}\right)\end{array}$ & $q_{\text {e-cal }}(\mathrm{mg} / \mathrm{g})$ & $h(\mathrm{mg} / \mathrm{g} \mathrm{h})$ & $\mathbf{R}^{2}$ & $\beta(\mathrm{mg} / \mathrm{g})$ & $\alpha(\mathrm{mg} / \mathrm{g} \cdot \mathrm{h})$ & $\mathbf{R}^{2}$ & $\begin{array}{l}k_{\text {id }}(g \\
\left.\mathrm{mg}^{-1} h^{-1 / 2}\right)\end{array}$ & $\mathrm{C}(\mathrm{mg} / \mathrm{g})$ & $\mathbf{R}^{2}$ & \\
\hline BSBC & 1.40 & 0.042 & 0.96 & 0.89 & 0.19 & 1.43 & 0.39 & 0.99 & 0.42 & 0.21 & 0.97 & 0.10 & 0.48 & 0.82 & 2 \\
\hline ZrBSBC6.5 & 4.06 & 0.065 & 1.50 & 0.89 & 0.10 & 4.15 & 1.75 & 0.99 & 1.56 & 0.57 & 0.90 & 0.26 & 1.65 & 0.70 & 2 \\
\hline ZrBSBC12.5 & 4.45 & 0.031 & 0.96 & 0.44 & 0.12 & 4.55 & 2.54 & 0.99 & 1.89 & 0.61 & 0.88 & 0.27 & 1.99 & 0.67 & 2 \\
\hline $\begin{array}{l}\text { Zr-FeBSBC } \\
(1: 20)\end{array}$ & 4.91 & 0.046 & 1.84 & 0.88 & 0.09 & 4.98 & 2.31 & 0.99 & 2.03 & 0.62 & 0.92 & 0.27 & 2.24 & 0.70 & 4 \\
\hline $\begin{array}{l}\text { Zr-FeCl3B- } \\
\text { SBC (1:5) }\end{array}$ & 4.78 & 0.052 & 1.96 & 0.88 & 0.08 & 4.86 & 2.03 & 0.99 & 2.22 & 0.61 & 0.91 & 0.28 & 2.10 & 0.70 & 4 \\
\hline FeBSBC & 3.76 & 0.046 & 2.05 & 0.94 & 0.07 & 3.85 & 1.05 & 0.99 & 1.10 & 0.60 & 0.90 & 0.26 & 1.25 & 0.71 & 3 \\
\hline $\mathrm{FeCl} 3 \mathrm{BSBC}$ & 3.53 & 0.063 & 2.27 & 0.89 & 0.05 & 3.69 & 0.67 & 0.99 & 0.78 & 0.60 & 0.97 & 0.27 & 0.91 & 0.83 & 2 \\
\hline
\end{tabular}

Table 1. Kinetic models and fitted parameters for $\mathrm{Sb}(\mathrm{V})$ sorption data.

Thus the presence of $\mathrm{Zr}$ and/or $\mathrm{Fe}$ in the $\mathrm{Sb}(\mathrm{V})$ solution at different $\mathrm{pH}$ shows a buffering effect ${ }^{46,47}$. The adsorption capacity of $\mathrm{Sb}(\mathrm{V})$ did not change greatly up to $\mathrm{pH}$. This might be due to the presence of undissociated $\mathrm{Sb}(\mathrm{V})$ species in the aqueous solution. Moreover, the $\mathrm{pHzpc}$ of BSBC, $\mathrm{ZrBSBC}_{6.5}, \mathrm{ZrBSBC}_{12.5}, \mathrm{Zr}-\mathrm{FeB}-$ $\mathrm{SBC}(1: 20), \mathrm{Zr}-\mathrm{FeCl}_{3} \mathrm{BSBC}(1: 5), \mathrm{Fe}-\mathrm{BSBC}$ and $\mathrm{FeCl}_{3}-\mathrm{BSBC}$ were 3.6, 3.7, 3.8, 6.2, 5.7, 3.9 and 3.8, (Figure S6), and $\mathrm{Sb}(\mathrm{V})$ being in undissociated form at this $\mathrm{pH}$ range. This subsequently suggest a likely influence of electrostatic binding. Additionally, zeta potential measurements confirmed net negative biochar surfaces at $\mathrm{pH}>\mathrm{pH}_{\mathrm{pzc}}$ (Figure S6). This explains the decrease in sorption capacity as the $\mathrm{pH}$ rises above $\mathrm{pH}_{\mathrm{pzc}}$.

Sorption kinetics. The kinetics data well fitted by the pseudo-second-order kinetics model (Table 1). Both pristine and modified biochars slowly adsorbed $\mathrm{Sb}(\mathrm{V})$ from aqueous solutions and reached equilibrium in $72 \mathrm{~h}$ (Fig. 4B). Antimonate sorption kinetics to biochars did not fit well with the first-order-kinetics and Elovich models. This is because the calculated $q_{e}$ and experimentally observed $q_{e}$ were extremely poor at initial $\mathrm{Sb}(\mathrm{V})$ concentration (Table 1 and Supporting Information). However, the kinetic data best fitted with the pseudosecond-order model with $R^{2}$ values $\geq 0.99$ (Table 1 ). This indicates the likelihood of chemisorption processes and not purely electrostatic interactions between the adsorbent and adsorbate ${ }^{48}$.

In this study, the initial linear part of the curve described the surface diffusion and the curve did not intersect through the origin $(C \neq 0)$ (Figure $S 7$ ) suggesting that intra-particle diffusion was not the only rate controlling phase but more than one process controls the sorption. Here, $\mathrm{Sb}(\mathrm{V})$ uptake was observed in apparent two phases: a sharper linear component attributed to $\mathrm{Sb}(\mathrm{V})$ diffusion of $\mathrm{Sb}(\mathrm{V})$ species to $\mathrm{ZrBSBC}_{6.5}, \mathrm{ZrBSBC}_{12.5}, \mathrm{Zr}$-FeBSBC (1:20), $\mathrm{Zr}-\mathrm{FeCl}_{3}$ (1:5), $\mathrm{FeBSBC}$ and $\mathrm{FeCl}_{3} \mathrm{BSBC}$ through boundary layer diffusion, subsequently followed by intra-particle diffusion (Figure S7).

Sorption isotherms. The adsorption of $\mathrm{Sb}(\mathrm{V})$ by all modified biochars increased rapidly in the concentration range of 1-10 $\mathrm{mg} \mathrm{L}^{-1}$ followed by a gradual increase thereafter (Fig. 5). Langmuir, Freundlich, Temkin and Dubinin-Radushkevich models were utilized to fit the experimental data (Table 2 and Fig. 5A-D). Despite the fact that all isotherms fitted well, the Freundlich and Dubinin-Radushkevich models reproduced $\mathrm{Sb}(\mathrm{V})$ sorption data overall to highest extent $\left(R^{2} \geq 0.99\right)$. This indicates that multilayer sorption was a potential sorption process mechanism for $\mathrm{Sb}(\mathrm{V})$ (Table 2 and Fig. 5B,D). Freundlich constant $K_{F}$ values spanned between 0.49 and 8.04 for all $\mathrm{Sb}(\mathrm{V})$ isotherm models with a slightly higher $K_{F}$ obtained for $\mathrm{ZrBSBC}_{12.5}$ than $\mathrm{Zr}-\mathrm{FeBSBC}(1: 20)$, respectively (Table 2). The sorption intensity or heterogeneity of a sorbent surface is indicated by the $1 / \mathrm{n}$ that reflects deviance from linearity. The $1 / \mathrm{n}$ values were in the order of $\mathrm{Zr}-\mathrm{FeBSBC}(1: 20)>\mathrm{Zr}-\mathrm{FeCl}_{3} \mathrm{BSBC}(1: 5)>\mathrm{Fe}-$ $\mathrm{BSBC}>\mathrm{Zr}-\mathrm{BSBC}_{6.5}>\mathrm{FeCl}_{3}-\mathrm{BSBC}>\mathrm{ZrBSBC}_{12.5}>\mathrm{BSBC}$; and spanned 0.583-0.813. This suggested that sorption process was favourable and chemical in nature belongs to the batch experimental conditions (Table 2$)^{31,49}$.

The maximum $\mathrm{Sb}(\mathrm{V})$ sorption capacities $\left(q_{m}\right)$ of biochars followed the order $\mathrm{Zr}-\mathrm{FeBSBC}(1: 20)>\mathrm{Zr}-\mathrm{FeCl}_{3} \mathrm{~B}-$

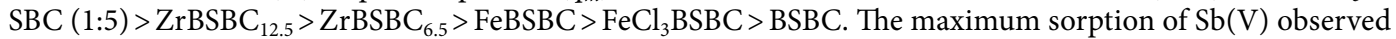
for $\mathrm{Zr}-\mathrm{FeBSBC}(1: 20), \mathrm{Zr}_{-} \mathrm{FeCl}_{3} \mathrm{BSBC}(1: 5), \mathrm{ZrBSBC}_{12.5},\left(98.04,85.47\right.$ and $\left.66.67 \mathrm{mg} \mathrm{g}^{-1}\right)$ followed by $\mathrm{ZrBSBC}_{6.5}$, FeBSBC, $\mathrm{FeCl}_{3} \mathrm{BSBC}$, BSBC, $\left(46.95,39.68,31.54\right.$, and $\left.17.54 \mathrm{mg} \mathrm{g}^{1}\right)$, respectively (Fig. 5A and Table 2).

The $R^{2}$ value for the Temkin model of BSBC was 0.93 . For modified biochars $R^{2}$ ranged from $0.91-0.98$ (Table 2 and Fig. 5C). In the Dubinin-Radushkevich (D-R) model, $R^{2}$ values were 0.99 (Fig. 5D and Table 2) for pristine and modified biochars, and the higher theoretical sorption of modified biochars were ascribed to its greater micro-porosity and reduced pore diameter. This outcome agreed with the greater SSA of the modified biochars. The bonding energy $E\left(\mathrm{~kJ} \mathrm{~mol}^{-1}\right)$ provides indirect data on the sorption mechanism, whether physical or chemical in nature. The calculated values between $8.57-9.20 \mathrm{~kJ} \mathrm{~mol}^{-1}$ indicate that the sorption system takes place chemically (chemisorption); values less than $8 \mathrm{~kJ} \mathrm{~mol}^{-1}$ indicate the system proceeds physically ${ }^{50}$.

Effect of major anions, major cations and ionic strength. The widely occurring anions such as $\mathrm{SO}_{4}{ }^{2-}, \mathrm{PO}_{4}{ }^{3-}$ and $\mathrm{CO}_{3}{ }^{2-}$ have been revealed to exhibit different effects on the adsorption of $\mathrm{Sb}^{17}$. The $\mathrm{Cl}^{-}, \mathrm{NO}_{3}{ }^{-}$, and $\mathrm{SO}_{4}{ }^{2-}$ did not pose any significant effect on $\mathrm{Sb}(\mathrm{V})$ sequestration because they have very minor affinities (between 3-6\%) (Figure S8A). Carbonate showed little effect on the sorption of $\mathrm{Sb}(\mathrm{V})$ even at $1.0 \mathrm{M}$. The sorption capacity of 

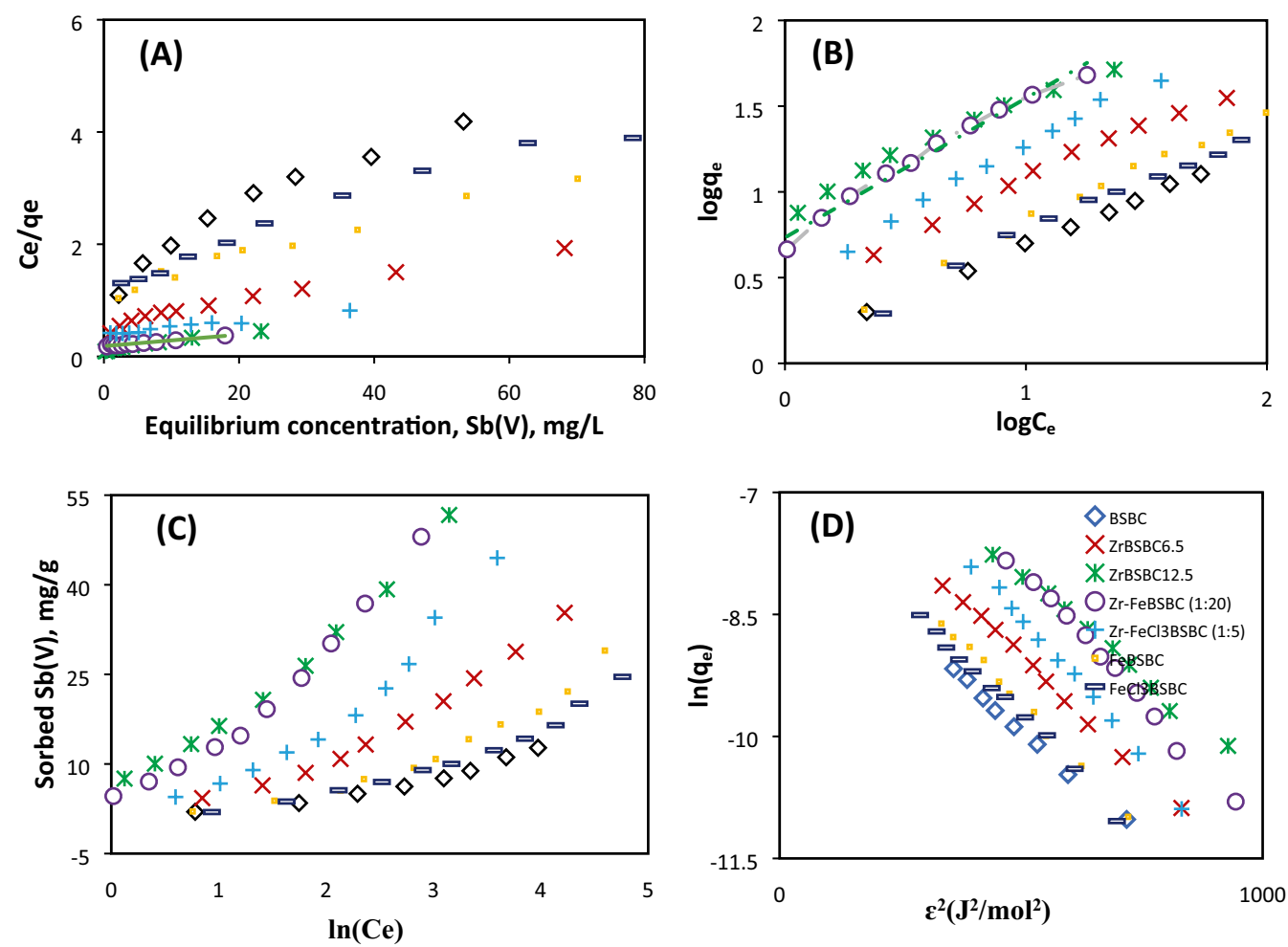

Figure 5. Isotherm model Langmuir (A), Freundlich (B), Temkin (C), and D-R (D) (Initial Sb(V) concentration was 5-250 $\mathrm{mg} / \mathrm{L}$, biochar density was $4 \mathrm{~g} / \mathrm{L}$ at $22{ }^{\circ} \mathrm{C}$ ).

$\mathrm{Sb}(\mathrm{V})$ decreased slightly (up to $12 \%$ ) from 5.13 to $4.45 \mathrm{mg} \mathrm{g}^{-1}$ (96.44-84.07\%) due to the presence of $\mathrm{CO}_{3}{ }^{2}$. It is possibly because the $\mathrm{Cl}^{-}, \mathrm{NO}_{3}{ }^{-}, \mathrm{CO}_{3}{ }^{2-}, \mathrm{SO}_{4}{ }^{2-}$ anions could mainly form outer-sphere complexes with biochar and thus affected $\mathrm{Sb}(\mathrm{V})$ sorption to minimal extent ${ }^{51}$. Analogously, much more significant retardation of $\mathrm{PO}_{4}{ }^{3-}$ on $\mathrm{Sb}(\mathrm{V})$ sorption was observed, and the sorption capacity decreased (27\%) from 4.73 to $3.46 \mathrm{mg} \mathrm{g}^{-1}$ (94.86-71.31\%) (Figure S8A) even at $0.01 \mathrm{M} \mathrm{PO}_{4}{ }^{3-}$. The impact of $\mathrm{PO}_{4}{ }^{3-}$ was particularly evident in the $\mathrm{Zr}$ FeBSBC (1:20), which similarly indicates a specific sorption mechanism in this adsorbent. These results were consistent with previous studies on the $\mathrm{Sb}(\mathrm{V})$ adsorption onto $\mathrm{Ce}(\mathrm{III})$-doped $\mathrm{Fe}_{3} \mathrm{O}_{4}$ particles ${ }^{46}$, magnetic sludge particles ${ }^{52}$ and La-doped magnetic biochars ${ }^{53}$. In addition, $\mathrm{PO}_{4}{ }^{3-}$ may undergo inner-sphere complexation with oxy-hydroxide compounds and compete with the same sorption sites of the biochar composites. The influence of interfering major cations such as $\mathrm{Na}^{+}, \mathrm{K}^{+}, \mathrm{Mg}^{2+}$, and $\mathrm{Ca}^{2+}$ of $\mathrm{Sb}(\mathrm{V})$ revealed that no notable changes in $\mathrm{Sb}(\mathrm{V})$ sorption (Figure S8B). In this study, a higher ionic strength significantly decreased the sorption capacity by $10.85 \%$ (3.37-3.04 mg/g), $19.23 \%$ (4.73-3.82 mg/g), 11.88\% (5.05-4.45 mg/g), 6.35\% (5.35-5.01 mg/g), 11.71\% $(5.12-4.52 \mathrm{mg} / \mathrm{g}), 17.18 \%(4.54-3.76 \mathrm{mg} / \mathrm{g})$ and $14.85 \%(4.85-4.13 \mathrm{mg} / \mathrm{g})$ for BSBC, $\mathrm{ZrBSBC}_{6.5}, \mathrm{ZrBSBC}_{12.5}$, $\mathrm{Zr}-\mathrm{FeBSBC}(1: 20), \mathrm{Zr}-\mathrm{FeCl}_{3} \mathrm{BSBC}(1: 5)$, FeBSBC, and $\mathrm{FeCl}_{3} \mathrm{BSBC}$, respectively, when $\mathrm{NaNO}_{3}$ concentrations increased from 0.01-1.0 M (Figure S9A). At high concentrations, the $\mathrm{NO}_{3}{ }^{-}$anion may compete with $\mathrm{Sb}(\mathrm{OH})_{6}{ }^{-}$ for the available sites on the biochar surface, and reduce $\mathrm{Sb}(\mathrm{V})$ reaction with the biochar ${ }^{54,55}$. However, as shown below, $\mathrm{NO}^{-}$did not influence $\mathrm{Sb}(\mathrm{V})$ sorption. Secondly, $\mathrm{Sb}(\mathrm{V})$ exists mainly as highly polymerised hydroxylnitro complexes or colloidal hydrous oxides in the presence of high $\mathrm{NO}_{3}{ }^{-}$concentrations ${ }^{56}$. In this research, $0.01 \mathrm{M} \mathrm{NaNO}_{3}{ }^{-}$is considered as an ideal background electrolyte.

Chemistry of $\mathrm{Sb}(\mathrm{V})$ binding mechanisms onto biochars. Antimonate exists in solution predominantly as an anionic species and thus it is expected to bind to biochars largely via ion exchange and ligand exchange mechanisms. Broadly speaking, $\mathrm{Sb}(\mathrm{V})$ removal from an aqueous solution via sorption onto $\mathrm{Zr}-\mathrm{BSBC}, \mathrm{Zr}-\mathrm{FeBSBC}$ and FeBSBC may be due to one or more factors such as: (1) electrostatic attraction, (2) nodule formation through hydrogen bonding, and (3) surface complexation or ligand exchange. Only at a $\mathrm{pH}<2$ does $\mathrm{Sb}(\mathrm{V})$ form positively charged species to any significant degree. Also, it can be assumed that at $\mathrm{pH}<4$, the biochar composites should behave as weak acids and a net positive surface charge predominated. The $\mathrm{ZP}$ and $\mathrm{pH}_{\mathrm{PZC}}$ of $\mathrm{BSBC}, \mathrm{ZrBSBC}_{6.5}$, $\mathrm{ZrBSBC}_{12.5}, \mathrm{Zr}-\mathrm{FeBSBC}, \mathrm{Zr}-\mathrm{FeCl}_{3} \mathrm{BSBC}$, Fe-BSBC and $\mathrm{FeCl}_{3}-\mathrm{BSBC}$ confirmed a positive in this $\mathrm{pH}$ range. Antimonate being in an undissociated form in the $\mathrm{pH}<\mathrm{pH}_{\mathrm{PZC}}$, an important sorption mechanism between the aqueous $\mathrm{Sb}(\mathrm{OH})_{6}^{-}$species is likely to be electrostatic attraction. The $\mathrm{Zr}$ content in $\mathrm{ZrBSBC}$ plays an important role in increasing $\mathrm{Sb}(\mathrm{V})$ sorption. However, the presence of $\mathrm{Zr}$ and Fe resulted in the greatest removal of $\mathrm{Sb}(\mathrm{V})$ from the solution. The presence of $\mathrm{Zr}$ and Fe resulted in the greatest removal of $\mathrm{Sb}(\mathrm{V})$ from the solution. This may be due to the enhanced SSA (specific surface area) from the $\mathrm{Zr}$-Fe coatings on biochar surface and an increase in the positive surface charge produced compared to pristine biochar, which is responsible for higher Sb uptake. Thermodynamic results demonstrated that $\mathrm{Sb}(\mathrm{V})$ sorption was more favourable with an increase in temperature 


\begin{tabular}{|c|c|c|c|c|c|c|c|c|c|c|c|c|c|c|c|c|c|c|}
\hline \multirow[b]{2}{*}{ Biochar } & \multirow[b]{2}{*}{$\begin{array}{l}q_{\exp } \\
(\mathrm{mg} / \mathrm{g})\end{array}$} & \multicolumn{5}{|c|}{ Langmuir model parameters } & \multicolumn{4}{|c|}{ Freundlich model parameters } & \multicolumn{3}{|c|}{$\begin{array}{l}\text { Temkin model } \\
\text { parameters }\end{array}$} & \multicolumn{4}{|c|}{$\begin{array}{l}\text { Dubinin-Radushkevich model } \\
\text { parameters }\end{array}$} & \multirow[t]{2}{*}{$\mathrm{pH}$} \\
\hline & & $\begin{array}{l}\mathbf{q}_{\mathrm{cal}} \\
(\mathrm{mg} / \mathrm{g})\end{array}$ & $\begin{array}{l}\mathrm{qm}_{\mathrm{m}} \\
(\mathrm{mg} / \mathrm{g})\end{array}$ & $\begin{array}{l}\mathrm{K}_{\mathrm{L}}(\mathrm{L} \\
\left.\mathrm{mg}^{-1}\right)\end{array}$ & $\mathbf{R}_{\mathbf{L}}$ & $\mathbf{R}^{2}$ & $\begin{array}{l}\mathbf{q}_{\mathrm{cal}} \\
(\mathrm{mg} / \mathrm{g})\end{array}$ & $\begin{array}{l}K_{F}(g \\
\left.m^{-1} h^{-1}\right)\end{array}$ & $1 / n$ & $\mathbf{R}^{2}$ & $\begin{array}{l}\text { b }(\mathrm{J} / \\
\mathrm{mol})\end{array}$ & $A(L / g)$ & $\mathbf{R}^{2}$ & $\begin{array}{l}\mathrm{q}_{\mathrm{m}} \\
(\mathrm{mg} / \mathrm{g})\end{array}$ & \begin{tabular}{|l}
$\mathrm{E}(\mathrm{kJ}$ \\
$\left.\mathrm{mol}^{-1}\right)$
\end{tabular} & $\beta$ & $\mathbf{R}^{2}$ & \\
\hline BSBC & 12.71 & 12.07 & 17.54 & 0.041 & $\begin{array}{l}0.18- \\
0.69\end{array}$ & 0.95 & 12.90 & 1.27 & 0.584 & 0.99 & 731.6 & 0.56 & 0.93 & 80.23 & 9.80 & $5.2 \times 10^{-3}$ & 0.99 & 2 \\
\hline $\begin{array}{l}\mathrm{ZrB-} \\
\mathrm{SBC}_{6.5}\end{array}$ & 35.31 & 34.10 & 46.95 & 0.039 & $\begin{array}{l}0.11- \\
0.71 \\
\end{array}$ & 0.98 & 39.92 & 2.719 & 0.636 & 0.99 & 261 & 0.46 & 0.96 & 253.26 & 9.36 & $5.7 \times 10^{-3}$ & 0.99 & 2 \\
\hline $\begin{array}{l}\mathrm{ZrB-} \\
\mathrm{SBC}_{12.5}\end{array}$ & 51.68 & 49.45 & 66.67 & 0.123 & \begin{tabular}{|l}
$0.03-$ \\
0.44 \\
\end{tabular} & 0.97 & 57.83 & 8.039 & 0.627 & 0.98 & 177.45 & 1.23 & 0.98 & 508.96 & 9.90 & $5.1 \times 10^{-3}$ & 0.99 & 2 \\
\hline \multirow{3}{*}{$\begin{array}{l}\mathrm{Zr}-\mathrm{FeB}- \\
\mathrm{SBC} \\
(1: 20)\end{array}$} & 47.12 & 41.60 & -31.8 & -0.033 & $\begin{array}{l}1.52- \\
0.16\end{array}$ & 0.54 & 33.89 & 0.910 & 1.271 & 0.92 & 153.94 & 0.39 & 0.63 & 4395 & 6.93 & $1.0 \times 10^{-2}$ & 0.90 & 2 \\
\hline & 48.81 & 47.07 & -60.61 & -0.037 & $4.0-0.14$ & 0.67 & 42.58 & 1.986 & 1.248 & 0.97 & 116.26 & 0.49 & 0.81 & 3202 & 7.58 & $8.7 \times 10^{-3}$ & 0.96 & 3 \\
\hline & 48.04 & 48.84 & 98.04 & 0.055 & $\begin{array}{l}0.077- \\
0.63\end{array}$ & 0.96 & 56.56 & 5.41 & 0.8128 & 0.98 & 162.64 & 1.01 & 0.96 & 1120 & 9.77 & $6.5 \times 10^{-3}$ & 0.99 & 4 \\
\hline \multirow{4}{*}{$\begin{array}{l}\mathrm{Zr}- \\
\mathrm{FeCl}_{3} \mathrm{~B}- \\
\mathrm{SBC} \\
(1: 5)\end{array}$} & 38.80 & 36.40 & 70.42 & 0.011 & \begin{tabular}{|l}
$0.89-$ \\
0.29
\end{tabular} & 0.96 & 31.43 & 1.633 & 0.796 & 0.99 & 251.55 & 0.42 & 0.89 & 456 & 8.45 & $7.0 \times 10^{-3}$ & 0.99 & 2 \\
\hline & 44.16 & 37.64 & 125 & 0.014 & $\begin{array}{l}0.87- \\
0.25\end{array}$ & 0.49 & 39.20 & 1.929 & 0.883 & 0.99 & 173.58 & 0.37 & 0.86 & 644 & 8.45 & $7.0 \times 10^{-3}$ & 0.98 & 3 \\
\hline & 44.49 & 44.47 & 85.47 & 0.029 & $\begin{array}{l}0.13- \\
0.76\end{array}$ & 0.97 & 50.08 & 3.12 & 0.772 & 0.99 & 185.73 & 0.54 & 0.93 & 727 & 9.57 & $6.8 \times 10^{-3}$ & 0.99 & 4 \\
\hline & 47.36 & 35.44 & 112.36 & 0.017 & $\begin{array}{l}0.85- \\
0.21\end{array}$ & 0.20 & 35.81 & 2.139 & 0.857 & 0.94 & 229.9 & 0.51 & 0.82 & 274 & 9.62 & $5.4 \times 10^{-3}$ & 0.93 & 5 \\
\hline \multirow{3}{*}{ FeBSBC } & 39.80 & 32.91 & 120.48 & 0.006 & $\begin{array}{l}0.93- \\
0.41\end{array}$ & 0.35 & 32.16 & 1.13 & 0.833 & 0.99 & 260.03 & 0.32 & 0.76 & 325 & 8.45 & $7.0 \times 10^{-3}$ & 0.98 & 2 \\
\hline & 28.98 & 26.51 & 39.68 & 0.02 & $\begin{array}{l}0.18- \\
0.83\end{array}$ & 0.95 & 30.29 & 1.36 & 0.6739 & 0.99 & 365.14 & 0.35 & 0.91 & 181 & 8.98 & $6.2 \times 10^{-3}$ & 0.99 & 3 \\
\hline & 41.26 & 36.53 & 49.26 & 0.071 & $\begin{array}{l}0.006- \\
0.57\end{array}$ & 0.91 & 43.39 & 4.684 & 0.603 & 0.88 & 238.79 & 0.86 & 0.93 & 444 & 9.21 & $5.9 \times 10^{-3}$ & 0.93 & 4 \\
\hline \multirow{2}{*}{$\begin{array}{l}\mathrm{FeCl}_{3} \mathrm{~B}- \\
\mathrm{SBC}\end{array}$} & 41.76 & 34.67 & 270.27 & 0.003 & $\begin{array}{l}0.96- \\
0.57\end{array}$ & 0.21 & 35.16 & 1.0139 & 0.9447 & 0.99 & 216.26 & 0.31 & 0.80 & 799 & 7.71 & $8.4 \times 10^{-3}$ & 0.99 & 2 \\
\hline & 24.60 & 22.66 & 31.54 & 0.022 & $\begin{array}{l}0.17- \\
0.81\end{array}$ & 0.95 & 26.08 & 1.313 & 0.6279 & 0.98 & 432.41 & 0.34 & 0.92 & 135 & 9.20 & $5.9 \times 10^{-3}$ & 0.99 & 3 \\
\hline
\end{tabular}

Table 2. Sorption isotherm models and best-fit parameters for $\mathrm{Sb}(\mathrm{V})$ sorption data.

\begin{tabular}{|c|c|c|c|c|c|c|c|c|c|c|}
\hline \multirow[b]{2}{*}{ Biochar } & \multicolumn{6}{|c|}{$\Delta \mathrm{G}\left(\mathrm{kJ} \mathrm{mol} \mathrm{m}^{-1}\right)$} & \multirow[b]{2}{*}{$\Delta \mathbf{H}\left(\mathbf{k J ~ m o l} \mathbf{~ m o ~}^{-1)}\right.$} & \multirow[b]{2}{*}{$\Delta \mathrm{S}(\mathrm{Kl} / \mathrm{mol} . \mathrm{K})$} & \multirow[b]{2}{*}{$\mathbf{R}^{2}$} & \multirow[b]{2}{*}{ pH } \\
\hline & $277 \mathrm{~K}$ & $288 K$ & $293 \mathrm{~K}$ & $298 \mathrm{~K}$ & $303 \mathrm{~K}$ & $310 \mathrm{~K}$ & & & & \\
\hline BSBC & 2.92 & 1.54 & -0.29 & -0.71 & -1.71 & -2.83 & 52.8 & 0.18 & 0.98 & 2 \\
\hline $\mathrm{ZrBSBC}_{6.5}$ & 1.58 & -0.23 & -0.48 & -1.83 & -2.57 & -3.19 & 43.1 & 0.15 & 0.98 & 2 \\
\hline $\mathrm{ZrBSBC}_{12.5}$ & -0.08 & -1.31 & -1.97 & -2.78 & -3.68 & -4.54 & 38.3 & 0.14 & 0.99 & 2 \\
\hline Zr-FeBSBC (1:20) & -0.78 & -2.52 & -3.86 & -4.66 & -5.67 & -7.26 & 53.7 & 0.2 & 0.99 & 4 \\
\hline $\mathrm{Zr}-\mathrm{FeCl}_{3} \mathrm{BSBC}(1: 5)$ & -0.36 & -1.79 & -2.48 & -3.37 & -4.67 & -5.72 & 45.7 & 0.16 & 0.98 & 4 \\
\hline FeBSBC & -0.27 & -1.45 & -2.07 & -2.42 & -2.71 & -3.41 & 25.6 & 0.09 & 0.99 & 3 \\
\hline $\mathrm{FeCl}_{3} \mathrm{BSBC}$ & 0.67 & -0.10 & -0.37 & -1.14 & -1.94 & -2.98 & 31.43 & 0.11 & 0.95 & 3 \\
\hline
\end{tabular}

Table 3. Thermodynamic parameters for the sorption of $\mathrm{Sb}(\mathrm{V})$ on biochars.

which suggested chemisorption (surface complexation) (Table 3 and Figure S9B). The empty d-orbitals on $\mathrm{Zr}$ and $\mathrm{Fe}$ might facilitate the complexation of $\mathrm{Sb}(\mathrm{V})$ through the formation of inner-sphere $\mathrm{Zr}-\mathrm{O}-\mathrm{Sb}, \mathrm{Zr}-\mathrm{O}-\mathrm{Fe}-$ $\mathrm{Sb}$, and $\mathrm{Fe}-\mathrm{O}-\mathrm{Sb}$ complex or via hydrogen bonding. Results from TEM and XPS demonstrate surfaced induced changes in the $\mathrm{Sb}$ oxidation state. TEM images suggest a concentration of $\mathrm{Sb}$ or potential surface precipitation on the biochars. In addition, despite the experimental systems being open to the atmosphere (i.e. oxic), XPS analysis indicates substantial surface-induced reduction of $\mathrm{Sb}(\mathrm{V})$. Biochar has previously been implicated in serving as an electron shuttle, allowing potentially for chemically induced transformation of oxidized species ${ }^{31,44,49}$. The presence of $\mathrm{Sb}$ (III) and Sb-enriched crystalline materials suggest more complex surface processes than adsorption or homogenous precipitation mechanisms in pristine, $\mathrm{Fe}$ or $\mathrm{Zr}$ modified biochars. Especially under acidic conditions, the reduction of $\mathrm{Sb}(\mathrm{V})$ to $\mathrm{Sb}(\mathrm{III})$ may indicate the surface-induced precipitation of $\mathrm{SbO}_{3}$. In this study, the hypothesis could not be confirmed. Nevertheless, the surface reduction of $\mathrm{Sb}(\mathrm{V})$ under oxic conditions has important implications for the application of biochars in contaminated waters or soils, due to the difference in toxicity and sorption behaviour. 
Materials and methods

Preparation of pristine biochar. Pristine biochar was produced from biosolids. The feedstock was airdried, ground ( $<1 \mathrm{~mm}, 50 \mathrm{mesh}$ ), and heated in a muffle furnace followed by placing in a ceramic crucible under an $\mathrm{N}_{2}$ atmosphere. The heating rate of $7^{\circ} \mathrm{C} \mathrm{min}^{-1}$ was employed using slow pyrolysis with holding at a peak temperature of $300^{\circ} \mathrm{C}$ for $30 \mathrm{~min}^{32}$. The resulting biosolid biochar (BSBC) samples were cooled at room temperature inside the furnace. Afterwards, the BSBC was removed from the furnace, stored in airtight plastic containers and preserved in a desiccator for further experiments.

Modification of biochar. The Zr-BSBC composites were synthesized by employing an in-situ precipitation method $^{49}$. In this study, a solution containing $5.0 \mathrm{~g}$ of BSBC and $50 \mathrm{~mL} 0.1 \mathrm{M}$ zirconium (IV) chloride solution $\left(\mathrm{ZrOCl}_{2} .8 \mathrm{H}_{2} \mathrm{O}\right.$ ) was brought to: i) $\mathrm{pH} 6.5$ and ii) $\mathrm{pH} 12.5$ through dropwise introduction of $0.1 \mathrm{M} \mathrm{NaOH}$. The resulting suspension was aged for $12 \mathrm{~h}$ at room temperature. These two synthesized $\mathrm{Zr}-\mathrm{BSBC}$ composites were rinsed several times by purified water to remove impurities after centrifugation at $5842 \mathrm{~g}$ for $15 \mathrm{~min}$ and followed by drying in an oven at $80^{\circ} \mathrm{C}$. The synthesized biochar composites (coded as $\mathrm{Zr}-\mathrm{BSBC}_{6.5}$ and $\mathrm{Zr}-\mathrm{BSBC}_{12.5}$ ) were preserved in a desiccator for further experiments.

Seven types of $\mathrm{Zr}-\mathrm{Fe}$ and $\mathrm{Zr}-\mathrm{FeCl}_{3}$ biochar composites were synthesized from $\mathrm{Fe}$ chips and $\mathrm{FeCl}_{3} \cdot 6 \mathrm{H}_{2} \mathrm{O}$ at $\mathrm{pH}$ 6.5. The $\mathrm{Zr}$ to Fe molar ratios were 1:1, 1:2, 1:5, 1:10, 1:20, 1:50 and 1:100. The biochar suspensions were shaken for $24 \mathrm{~h}$ and centrifuged at $5842 \mathrm{~g}$ for $15 \mathrm{~min}$, followed by decanting. Then, the synthesized biochar composites were rinsed several times by purified water, centrifuged at $5842 \mathrm{~g}$ for $15 \mathrm{~min}$ and dried in an oven at $80{ }^{\circ} \mathrm{C}$. In addition, a Fe-only modified biochar was produced from iron chips (Fe-BSBC) and iron chloride $\left(\mathrm{FeCl}_{3}-\mathrm{BSBC}\right)$ as described above.

Characterization of adsorbents. Surface charge was characterised viz. zeta potential (ZP), point of zero charge $\left(\mathrm{pH}_{\mathrm{PZC}}\right)$ and cation exchange capacity (CEC) using a NanoPlus HD analyser (Micromeritics, USA), Brunauer-Emmett-Teller (BET) for specific surface area (SSA). Pore size distribution and pore volume were determined using $\mathrm{N}_{2}$ sorption (Tristar II 3020, Micromeritics, USA) and the elemental composition (C, N, S) measured using a LECO TruMac C/N/S. The surface functional groups and morphology was investigated with Fourier transform infrared (FT-IR, Agilent Cary 600), X-ray diffraction (XRD, Empyrean, PANanalytical) and Environmental Scanning Electron Microscopy (SEM, Zeiss Sigma, Germany) equipped with a Bruker energy dispersive X-ray spectroscopy (EDS) detector. Additionally, the micromorphology of biochar samples were determined using a high-resolution transmission electron microscope (HRTEM, JEM-2100F, Japan) coupled with EDS detector (JEOL-JED-2300). Antimony in all aqueous samples was determined by using inductively coupled plasma optical emission spectrometry (ICP-OES, PerkinElmer Avio 200, USA). The elemental oxidation number, surface composition and speciation of sorbed $\mathrm{Sb}$ on the biochars surface also determined by XPS (ESCALAB250Xi, Thermo Scientific, UK, mono-chromated Al K alpha).

Batch sorption experiments: $\mathrm{pH}$, adsorption kinetics, and isotherms. Sorption edge investigations were achieved in the $\mathrm{pH}$ range of $1-10$ at an initial $\mathrm{Sb}(\mathrm{V})$ concentrations of $10 \mathrm{mg} \mathrm{L}^{-1}$ with a biochar density of $4 \mathrm{~g} \mathrm{~L}^{-1}$ at room temperature $\left(20 \pm 2{ }^{\circ} \mathrm{C}\right)$. The suspension $\mathrm{pH}$ was controlled by addition $0.1 \mathrm{M} \mathrm{HNO}_{3}$ and/or $0.1 \mathrm{M} \mathrm{NaOH}$. Kinetics studies were conducted using $0.1 \mathrm{~g}$ biochar in $25 \mathrm{~mL}$ solution (biochar to solution ratio $=1: 250$ ), which was added to $50 \mathrm{~mL}$ falcon tubes containing $5 \mathrm{mg} / \mathrm{L} \mathrm{Sb}(\mathrm{V})$ for $7 \mathrm{~d}$ at room temperature $\left(22 \pm 0.2^{\circ} \mathrm{C}\right)$. The background electrolyte was $0.01 \mathrm{M} \mathrm{NaNO}_{3}$ in ultrapure water. Following reactions, suspensions were centrifuged at $5842 \mathrm{~g}$ for $20 \mathrm{~min}$ and the supernatants were filtered through $0.22 \mu \mathrm{m}$ PES filters. Kinetic data were fitted with four classical kinetic models, namely the pseudo-first-order kinetic model, pseudosecond-order kinetic model, Elovich model and Intra-particle diffusion model.

Adsorption isotherms used a similar procedure as the kinetic experiments except using a range of $\mathrm{Sb}(\mathrm{V}) \mathrm{con}$ centrations (5-250 $\mathrm{mg} \mathrm{L}^{-1}$ ) for $72 \mathrm{~h}$ at $\mathrm{pH} \mathrm{2-10.} \mathrm{Four} \mathrm{sorption} \mathrm{isotherm} \mathrm{models} \mathrm{were} \mathrm{fitted} \mathrm{to} \mathrm{the} \mathrm{data,} \mathrm{namely}$ the Langmuir, Freundlich, Temkin and Dubinin-Radushkevich models (detailed information of all isotherm models in SI section).

Influence of biochar dosage, interfering ions, ionic strength and thermodynamics. To assess the impact of adsorbent dosage on $\mathrm{Sb}(\mathrm{V})$ sorption, different dosages of biochar (solid:solution) (1:100, 1:250, 1:500 and 1:1000) were added into $50 \mathrm{~mL}$ centrifuge tubes maintaining $\mathrm{pH}$ at $2-10$. Ionic strength $(0.01,0.1,0.5$ and $1.0 \mathrm{M}$ of $\left.\mathrm{NaNO}_{3}\right)$, coexisting anions $\left(\mathrm{Cl}^{-}, \mathrm{NO}_{3}{ }^{-}, \mathrm{SO}_{4}{ }^{2-}, \mathrm{CO}_{3}{ }^{2-}\right.$ and $\mathrm{PO}_{4}{ }^{3-}$ at concentrations of $\left.0.01-0.1 \mathrm{M}\right)$ and cations $(0.1 \mathrm{M}$ of $\mathrm{Na}, \mathrm{K}, \mathrm{Mg}$, and $\mathrm{Ca}$ ) were also studied. The $\mathrm{pH}$ of biochar samples were adjusted to 2.0 for BSBC, $\mathrm{ZrBSBC}_{6.5}, \mathrm{ZrBSBC}_{12.5}, \mathrm{FeBSBC}$ and 3.0 for $\mathrm{Zr}-\mathrm{FeBSBC}$ (1:20), Zr-FeCl3BSBC (1:5), $\mathrm{FeCl}_{3} \mathrm{BSBC}_{\text {, }}$ respectively. The $\mathrm{Sb}(\mathrm{V})$ concentration was $20 \mathrm{mg} / \mathrm{L}$, adding $0.1 \mathrm{~g}$ biochar in $25 \mathrm{~mL}$ solution. The thermodynamic studies were conducted by varying temperatures at $4,15,20,25,30$, and $37^{\circ} \mathrm{C}$. The thermodynamic parameters of the Gibbs free energy $(\Delta \mathrm{G})$, entropy $(\Delta \mathrm{S})$, and enthalpy $(\Delta \mathrm{H})$ and were calculated (details are provided in SI section).

Received: 30 December 2020; Accepted: 23 February 2021

Published online: 14 April 2021 


\section{References}

1. Filella, M., Belzile, N. \& Chen, Y.-W. Antimony in the environment: a review focused on natural waters: I. Occurrence. Earth-Sci. Rev. 57, 125-176 (2002).

2. Okkenhaug, G. et al. Antimony (Sb) and Arsenic (As) in Sb mining impacted paddy soil from Xikuangshan, China: differences in mechanisms controlling soil sequestration and uptake in rice. Environ. Sci. Technol. 46, 3155-3162. https://doi.org/10.1021/es202 2472 (2012).

3. Wang, X., He, M., Xi, J. \& Lu, X. Antimony distribution and mobility in rivers around the world's largest antimony mine of Xikuangshan, Hunan Province, China. Microchem. J. 97, 4-11. https://doi.org/10.1016/j.microc.2010.05.011 (2011).

4. Wu, Z., He, M., Guo, X. \& Zhou, R. Removal of antimony (III) and antimony (V) from drinking water by ferric chloride coagulation: competing ion effect and the mechanism analysis. Sep. Purif. Technol. 76, 184-190. https://doi.org/10.1016/j.seppur.2010.10. 006 (2010).

5. Ungureanu, G., Santos, S., Boaventura, R. \& Botelho, C. Arsenic and antimony in water and wastewater: overview of removal techniques with special reference to latest advances in adsorption. J. Environ. Manag. 151, 326-342 (2015).

6. Mitsunobu, S., Takahashi, Y., Terada, Y. \& Sakata, M. Antimony(V) incorporation into synthetic ferrihydrite, goethite, and natural iron oxyhydroxides. Environ. Sci. Technol. 44, 3712-3718. https://doi.org/10.1021/es903901e (2010).

7. Mitsunobu, S., Takahashi, Y., Terada, Y. \& Sakata, M. Antimony (V) incorporation into synthetic ferrihydrite, goethite, and natural iron oxyhydroxides. Environ. Sci. Technol. 44, 3712-3718 (2010).

8. Filella, M., Williams, P. A. \& Belzile, N. Antimony in the environment: knowns and unknowns. Environ. Chem. 6, 95-105 (2009).

9. Gebel, T. Arsenic and antimony: comparative approach on mechanistic toxicology. Chem. Biol. Interact. 107, 131-144 (1997).

10. IARC, (International agency for research on cancer). IARC Monographs on the Evaluation of Carcinogenic Risks to Humans. IARC Monogr. 831,Vol. 85 (2004). https://monographs.iarc.who.int/wp-content/uploads/2018/06/mono85.pdf

11. Guo, X. et al. Adsorption of antimony onto iron oxyhydroxides: adsorption behavior and surface structure. J. Hazard. Mater. 276, 339-345 (2014).

12. Luo, F., Yang, D., Chen, Z., Megharaj, M. \& Naidu, R. The mechanism for degrading Orange II based on adsorption and reduction by ion-based nanoparticles synthesized by grape leaf extract. J. Hazard. Mater. 296, 37-45. https://doi.org/10.1016/j.jhazmat.2015. 04.027 (2015).

13. Luo, J. et al. Removal of antimonite ( $\mathrm{Sb}(\mathrm{III})$ ) and antimonate (Sb (V)) from aqueous solution using carbon nanofibers that are decorated with zirconium oxide (ZrO2). Environ. Sci. Technol. 49, 11115-11124 (2015).

14. Salam, M. A. \& Mohamed, R. M. Removal of antimony (III) by multi-walled carbon nanotubes from model solution and environmental samples. Chem. Eng. Res. Des. 91, 1352-1360 (2013).

15. Miao, Y. et al. Antimony (V) removal from water by hydrated ferric oxides supported by calcite sand and polymeric anion exchanger. J. Environ. Sci. 26, 307-314 (2014).

16. Leng, Y., Guo, W., Su, S., Yi, C. \& Xing, L. Removal of antimony (III) from aqueous solution by graphene as an adsorbent. Chem. Eng. J. 211, 406-411 (2012).

17. Wang, L. et al. Mechanism of enhanced $\mathrm{Sb}(\mathrm{V})$ removal from aqueous solution using chemically modified aerobic granules. $J$. Hazard. Mater. 284, 43-49. https://doi.org/10.1016/j.jhazmat.2014.10.041 (2015).

18. Xu, W., Wang, H., Liu, R., Zhao, X. \& Qu, J. The mechanism of antimony(III) removal and its reactions on the surfaces of Fe-Mn Binary Oxide. J. Colloid Interface Sci. 363, 320-326. https://doi.org/10.1016/j.jcis.2011.07.026 (2011).

19. Biswas, B. K., Inoue, J.-I., Kawakita, H., Ohto, K. \& Inoue, K. Effective removal and recovery of antimony using metal-loaded saponified orange waste. J. Hazard. Mater. 172, 721-728 (2009).

20. Xi, J., He, M. \& Lin, C. Adsorption of antimony(III) and antimony(V) on bentonite: Kinetics, thermodynamics and anion competition. Microchem. J. 97, 85-91. https://doi.org/10.1016/j.microc.2010.05.017 (2011).

21. Saeidnia, S., Asadollahfardi, G. \& Khodadadi Darban, A. Simulation of adsorption of antimony on zero-valent iron nanoparticles coated on the industrial minerals (kaolinite, bentonite and perlite) in mineral effluent. Desalination Water Treat. 57, 22321-22328 (2016).

22. Zou, J. P. et al. Three-dimensional reduced graphene oxide coupled with $\mathrm{Mn}_{3} \mathrm{O}_{4}$ for highly efficient removal of $\mathrm{Sb}$ (III) and $\mathrm{Sb}$ (V) from Water. ACS Appl. Mater. Interfaces. 8, 18140-18149. https://doi.org/10.1021/acsami.6b05895 (2016).

23. Luo, J. et al. Antimony removal from aqueous solution using novel $\alpha-\mathrm{MnO} 2$ nanofibers: equilibrium, kinetic, and density functional theory studies. ACS Sustain. Chem. Eng. 5, 2255-2264 (2017).

24. Yan, L., Song, J., Chan, T. \& Jing, C. Insights into antimony adsorption on $\mathrm{TiO}_{2}$ : XAFS and DFT study. Environ. Sci. Technol. 51, 6335-6341. https://doi.org/10.1021/acs.est.7b00807 (2017).

25. He, X., Min, X. \& Luo, X. Efficient removal of antimony (III, V) from contaminated water by amino modification of a zirconium metal-organic framework with mechanism study. J. Chem. Eng. Data 62, 1519-1529 (2017).

26. Amen, R. et al. A critical review on arsenic removal from water using biochar-based sorbents: the significance of modification and redox reactions. Chem. Eng. J. 396, 125195. https://doi.org/10.1016/j.cej.2020.125195 (2020).

27. Leuz, A.-K., Mönch, H. \& Johnson, C. A. Sorption of Sb(III) and Sb(V) to goethite: influence on Sb(III) oxidation and mobilization. Environ. Sci. Technol. 40, 7277-7282. https://doi.org/10.1021/es061284b (2006).

28. He, X. et al. Exceptional adsorption of arsenic by zirconium metal-organic frameworks: engineering exploration and mechanism insight. J. Colloid Interface Sci. 539, 223-234 (2019).

29. Buschmann, J. \& Sigg, L. Antimony (III) binding to humic substances: influence of pH and type of humic acid. Environ. Sci. Technol. 38, 4535-4541 (2004).

30. Karimian, N., Burton, E. D. \& Johnston, S. G. Antimony speciation and mobility during Fe(II)-induced transformation of humic acid-antimony(V)-iron(III) coprecipitates. Environ. Pollut. 254, 113112. https://doi.org/10.1016/j.envpol.2019.113112 (2019).

31. Niazi, N. K. et al. Arsenic removal by perilla leaf biochar in aqueous solutions and groundwater: an integrated spectroscopic and microscopic examination. Environ. Pollut. 232, 31-41. https://doi.org/10.1016/j.envpol.2017.09.051 (2018).

32. Vithanage, M. et al. Mechanisms of antimony adsorption onto soybean stover-derived biochar in aqueous solutions. J. Environ. Manag. 151, 443-449. https://doi.org/10.1016/j.jenvman.2014.11.005 (2015).

33. Ambe, S. Adsorption kinetics of antimony (V) ions onto a-ferric oxide surfaces from an aqueous solution. Langmuir 3, 489-493 (1987).

34. Scheinost, A. C. et al. Quantitative antimony speciation in shooting-range soils by EXAFS spectroscopy. Geochim. Cosmochim. Acta 70, 3299-3312 (2006)

35. Wu, H. et al. Unusual and highly tunable missing-linker defects in zirconium metal-organic framework UiO-66 and their important effects on gas adsorption. J. Am. Chem. Soc. 135, 10525-10532. https://doi.org/10.1021/ja404514r (2013).

36. Ren, Z., Zhang, G. \& Paul Chen, J. Adsorptive removal of arsenic from water by an iron-zirconium binary oxide adsorbent. J. Colloid Interface Sci. 358, 230-237. https://doi.org/10.1016/j.jcis.2011.01.013 (2011).

37. Burton, E. D., Hockmann, K. \& Karimian, N. Antimony sorption to goethite: effects of Fe(II)-catalyzed recrystallization. ACS Earth Space Chem. 4, 476-487. https://doi.org/10.1021/acsearthspacechem.0c00013 (2020).

38. Zhao, X. et al. Antimonate and antimonite adsorption by a polyvinyl alcohol-stabilized granular adsorbent containing nanoscale zero-valent iron. Chem. Eng. J. 247, 250-257 (2014). 
39. Bollino, F., Armenia, E. \& Tranquillo, E. Zirconia/hydroxyapatite composites synthesized via Sol-Gel: Influence of hydroxyapatite content and heating on their biological properties. Materials 10, 757 (2017).

40. Testa, M. L. et al. Use of zirconium phosphate-sulphate as acid catalyst for synthesis of glycerol-based fuel additives. Catalysts https://doi.org/10.3390/catal9020148 (2019).

41. Merle-Mejean, T., Barberis, P., Othmane, S. B., Nardou, F. \& Quintard, P. Chemical forms of hydroxyls on/in zirconia: an FT-IR study. J. Eur. Ceram. Soc. 18, 1579-1586 (1998).

42. Dou, X., Mohan, D., Pittman, C. U. Jr. \& Yang, S. Remediating fluoride from water using hydrous zirconium oxide. Chem. Eng. J. 198, 236-245 (2012)

43. Hang, C., Li, Q., Gao, S. \& Shang, J. K. As(III) and As(V) adsorption by hydrous zirconium oxide nanoparticles synthesized by a hydrothermal process followed with heat treatment. Ind. Eng. Chem. Res. 51, 353-361. https://doi.org/10.1021/ie202260g (2012).

44. Kappler, A. et al. Biochar as an electron shuttle between bacteria and Fe (III) minerals. Environ. Sci. Technol. Lett. 1, 339-344 (2014).

45. Mallampati, R. \& Valiyaveettil, S. Apple peels: a versatile biomass for water purification?. ACS Appl. Mater. Interfaces. 5, 4443-4449 (2013).

46. Qi, Z., Joshi, T. P., Liu, R., Liu, H. \& Qu, J. Synthesis of Ce (III)-doped Fe3O4 magnetic particles for efficient removal of antimony from aqueous solution. J. Hazard. Mater. 329, 193-204 (2017).

47. Zheng, Y. M., Lim, S. F. \& Chen, J. P. Preparation and characterization of zirconium-based magnetic sorbent for arsenate removal. J. Colloid Interface Sci. 338, 22-29. https://doi.org/10.1016/j.jcis.2009.06.021 (2009).

48. Tian, Y. et al. Electrospun membrane of cellulose acetate for heavy metal ion adsorption in water treatment. Carbohyd. Polym. 83, 743-748. https://doi.org/10.1016/j.carbpol.2010.08.054 (2011).

49. Rahman, M. A. et al. Removal of arsenate from contaminated waters by novel zirconium and zirconium-iron modified biochar. $J$. Hazard. Mater. https://doi.org/10.1016/j.jhazmat.2020.124488 (2020).

50. Sarı, A., Şahinoğlu, G. N. R. \& Tüzen, M. Antimony (III) adsorption from aqueous solution using raw perlite and Mn-modified perlite: equilibrium, thermodynamic, and kinetic studies. Ind. Eng. Chem. Res. 51, 6877-6886 (2012).

51. Cumbal, L. \& SenGupta, A. K. Arsenic removal using polymer-supported hydrated iron (III) oxide nanoparticles: role of Donnan membrane effect. Environ. Sci. Technol. 39, 6508-6515 (2005).

52. Wang, L. et al. Highly efficient $\mathrm{As}(\mathrm{v}) / \mathrm{Sb}(\mathrm{v})$ removal by magnetic sludge composite: synthesis, characterization, equilibrium, and mechanism studies. RSC Adv. 6, 42876-42884. https://doi.org/10.1039/c6ra06208c (2016).

53. Wang, L. et al. Enhanced antimonate $(\mathrm{Sb}(\mathrm{V}))$ removal from aqueous solution by La-doped magnetic biochars. Chem. Eng. J. 354, 623-632. https://doi.org/10.1016/j.cej.2018.08.074 (2018).

54. Hayes, K. F., Papelis, C. \& Leckie, J. O. Modeling ionic strength effects on anion adsorption at hydrous oxide/solution interfaces. J. Colloid Interface Sci. 125, 717-726 (1988).

55. Leuz, A.-K., Mönch, H. \& Johnson, C. A. Sorption of Sb (III) and Sb (V) to goethite: influence on Sb (III) oxidation and mobilization. Environ. Sci. Technol. 40, 7277-7282 (2006).

56. Filella, M., Belzile, N. \& Chen, Y.-W. Antimony in the environment: a review focused on natural waters: II. Relevant solution chemistry. Earth-Sci. Rev. 59, 265-285 (2002).

\title{
Acknowledgements
}

The first author is thankful to the University of Newcastle for providing UNIPRS and UNRSC central scholarship including the Research Training Program allowances, and to the Department of Public Health Engineering (DPHE), Bangladesh for granting study leave for PhD program. The authors acknowledge the cooperation of the EMX unit at the University of Newcastle, Australia regarding the use and analysis support of XRD, SEM and TEM-EDS. We also thank Dr Bill Gong of the University of New South Wales' Mark Wainwright Analytical Centre for assistance with XPS analysis.

\section{Author contributions}

A.R.: Conceptualisation, Methodology, Formal analysis, Writing Original Draft; D.L.: Conceptualisation, Reviewing, Editing, Resources \& Supervision; M.M.R.: Reviewing, Editing \& Supervision; M.M.B.: Reviewing, Editing \& Supervision; P.S.: Reviewing, Editing \& Supervision.

\section{Competing interests}

The authors declare no competing interests.

\section{Additional information}

Supplementary Information The online version contains supplementary material available at https://doi.org/ 10.1038/s41598-021-86978-6.

Correspondence and requests for materials should be addressed to D.L.

Reprints and permissions information is available at www.nature.com/reprints.

Publisher's note Springer Nature remains neutral with regard to jurisdictional claims in published maps and institutional affiliations.

\begin{abstract}
Open Access This article is licensed under a Creative Commons Attribution 4.0 International License, which permits use, sharing, adaptation, distribution and reproduction in any medium or format, as long as you give appropriate credit to the original author(s) and the source, provide a link to the Creative Commons licence, and indicate if changes were made. The images or other third party material in this article are included in the article's Creative Commons licence, unless indicated otherwise in a credit line to the material. If material is not included in the article's Creative Commons licence and your intended use is not permitted by statutory regulation or exceeds the permitted use, you will need to obtain permission directly from the copyright holder. To view a copy of this licence, visit http://creativecommons.org/licenses/by/4.0/.
\end{abstract}

(c) The Author(s) 2021 